\title{
Role of cannabis in inflammatory bowel diseases
}

\author{
Abhilash Perisettia ${ }^{\text {, Afrina Hossain Rimu }}{ }^{\text {, }}$ Salman Ali Khanc, Pardeep Bansal ${ }^{\mathrm{d}}$, Hemant Goyale \\ University of Arkansas for Medical Sciences; Texas Tech University, Lubbock; Regional Hospital and Moses Taylor \\ Hospital, PA; The Wright Center for Graduate Medical Education, USA
}

\begin{abstract}
For many centuries, cannabis (marijuana) has been used for both recreational and medicinal purposes. Currently, there are about 192 million cannabis users worldwide, constituting approximately 3.9\% of the global population. Cannabis comprises more than 70 aromatic hydrocarbon compounds known as cannabinoids. Endogenous circulating cannabinoids, or endocannabinoids, such as anandamide and 2-arachidonoyl-glycerol, their metabolizing enzymes (fatty acid amide hydrolase and monoacylglycerol lipase) and 2 G-protein coupled cannabinoid receptors, CB1 and CB2, together represent the endocannabinoid system and are present throughout the human body. In the gastrointestinal (GI) tract, the activated endocannabinoid system reduces gut motility, intestinal secretion and epithelial permeability, and induces inflammatory leukocyte recruitment and immune modulation through the cannabinoid receptors present in the enteric nervous and immune systems. Because of the effects of cannabinoids on the GI tract, attempts have been made to investigate their medicinal properties, particularly for GI disorders such as pancreatitis, hepatitis, and inflammatory bowel diseases (IBD). The effects of cannabis on IBD have been elucidated in several small observational and placebo-controlled studies, but with varied results. The small sample size and short follow-up duration in these studies make it difficult to show the clear benefits of cannabis in IBD. However, cannabis is now being considered as a potential drug for inflammatory GI conditions, particularly IBD, because of its spreading legalization in the United States and other countries and the growing trend in its use. More high-quality controlled studies are warranted to elucidate the mechanism and benefits of cannabis use as a possible option in IBD management.
\end{abstract}

Keywords Cannabis, marijuana, inflammatory bowel diseases, Crohn's disease, ulcerative colitis, endocannabinoid

Ann Gastroenterol 2020; 33 (2): 1-11

\section{Introduction}

Cannabis/marijuana is predominantly derived from the plant Cannabis sativa, one of the earliest plants cultivated by human kind [1]. Cannabis was used extensively for

${ }^{a}$ Division of Gastroenterology and Hepatology, University of Arkansas for Medical Sciences (Abhilash Perisetti); ' Department of Nutritional Sciences, Texas Tech University, Lubbock, TX (Afrina Hossain Rimu); 'University of Arkansas for Medical Sciences, AR (Salman Ali Khan);

${ }^{\mathrm{d} D e p a r t m e n t ~ o f ~ G a s t r o e n t e r o l o g y, ~ R e g i o n a l ~ H o s p i t a l ~ a n d ~ M o s e s ~ T a y l o r ~}$ Hospital, PA (Pardeep Bansal); ${ }^{\mathrm{e} D e p a r t m e n t}$ of Medicine, The Wright Center for Graduate Medical Education (Hemant Goyal), USA

Conflict of Interest: Hemant Goyal holds stocks in Rimrock Gold Corp., Tauriga Sciences and SinglePoint Inc.

Correspondence to: Hemant Goyal, MD, FACP, Gastroenterology Fellow, The Wright Center for Graduate Medical Education, 111 North Washington Avenue Scranton, PA, 18503 USA, e-mail: doc.hemant@yahoo.com

Received 23 September 2019; accepted 26 November 2019; published online 12 February 2020

DOI: https://doi.org/10.20524/aog.2020.0452 various ailments in the past, even before it was identified to have a potential for dependency and abuse [2]. Therapeutic applications of cannabis for various conditions, such as rheumatic pain, constipation, female reproductive system disorders, etc., can be dated back more than 4000 years [3]. Despite its ancient roots, cannabis could not be used legally for a long time because of its many detrimental effects on the human body [4]. Use of cannabis in adolescents may lead to adverse psychiatric effects because of its neuro-modulatory mechanisms. Short- and long-term adverse effects of its use include altered brain development, memory and cognitive impairments, and altered judgment. Even psychosis and paranoia can occur if cannabis is consumed in high doses [5]. Increasing legalization of cannabis in the United States (US) and various other parts of the world have increased the prevalence of its use, particularly in youngsters aged between 18 and 25 years [6,7] (Fig. 1). However, 33 states and the District of Columbia in the US have very recently legalized cannabis for therapeutic purposes. Among the 33, 11 states have fully legalized its use, 10 have approved it for medical purpose alongside its decriminalization, while 11 other states have approved its use only for medicinal purposes [8]. In Europe, consumption of cannabis is a serious offense in some countries, 


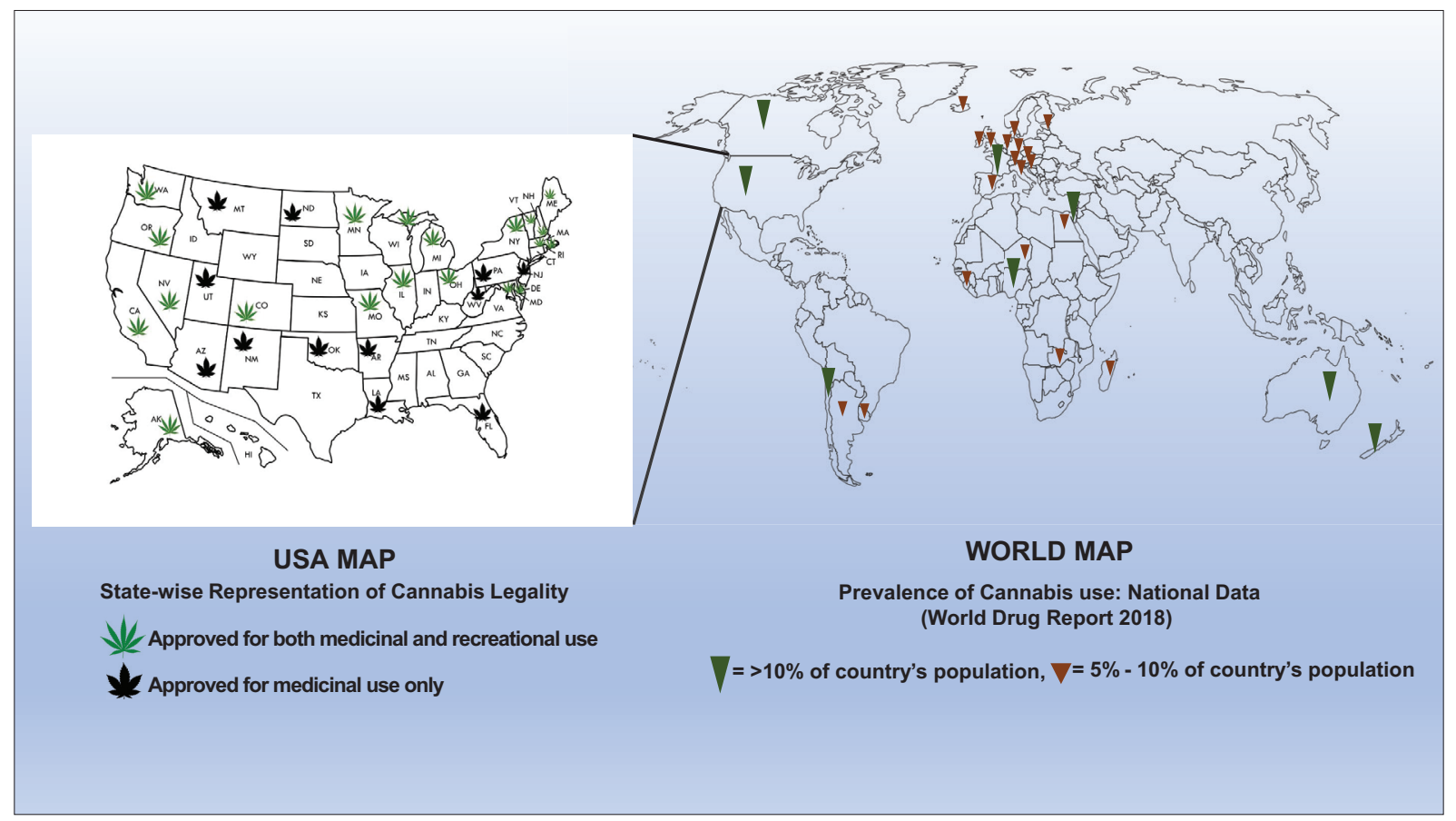

Figure 1 Worldwide distribution and prevalence of cannabis Use (Data adapted from Prevalence of drug use in general population: National Data) World Drug Report 2018; (Retrieved from: https://www.unodc.org/wdr2018/en/maps-and-graphs.html) and State-wise representation of cannabis legality in the United States of America. Data obtained from: https://disa.com/map-of-marijuana-legality-by-state

punishable with a prison sentence (in Cyprus, France, Finland, Greece, Hungary, Norway, and Sweden); but in countries like Estonia, Lithuania, Latvia and Portugal, consumption of cannabis can only lead to a fine or minor penalty. Similarly, unauthorized possession of small amount of cannabis can lead to in-prison punishment in some countries (Norway, Sweden, Finland, United Kingdom, Denmark, Estonia, Poland, Germany, France, Austria, Hungary, Romania, Slovakia, Czech Republic, and Greece), while in some other countries like Spain, Portugal, Italy, Ireland, Latvia, Lithuania, it is not punishable with incarceration and is considered a minor offense [9].

Though cannabis can cause many harmful effects, its medicinal properties cannot be denied. Cannabis sativa contains more than 70 different cannabinoids (phytocannabinoids) [10]. Among these, $\Delta^{9}$-tetrahydrocannabinol (THC) is the principle and most potent psychoactive ingredient [11]. Cannabidiol (CBD), cannabigerol and cannabichromene are some of the other natural cannabis compounds actively used for research purposes $[10,12,13]$, among which CBD has shown its potential as an anti-inflammatory agent without adverse psychotic effects $[14,15]$. Because of its neuroprotective effects, it is now approved for treating some rare forms of epilepsy [16]. CB1 and $\mathrm{CB} 2$ are the 2 receptor mediators through which cannabis exerts its actions on multiple organ systems, including the gastrointestinal (GI), nervous and immune systems [10]. Antiinflammatory and pain-modulating properties of cannabis have been demonstrated in multiple GI and related organ disorders in the past [17-19]. In recent years, the effects of cannabis on inflammatory bowel diseases (IBD) have been investigated in multiple investigational, clinically randomized, retrospective and survey studies. IBD is a chronic inflammatory disorder that can affect both the small and large intestines. It mainly comprises 2 entities: Crohn's disease (CD) and ulcerative colitis (UC) (though there is a third entity, unclassified or indeterminate IBD). In some in vivo experiments on animal models, cannabis showed strong anti-motility and antiinflammatory effects on the gut [20-23]. However, little is known about whether it has the same impact on the human colon. Lately, some observational and small placebo-controlled studies have been conducted to examine the effects of cannabis on IBD, and some of these studies have shown promising results [11,24-26]. However, given the lack of sufficient large clinical trials, it remains a question whether it can be used as a successful therapeutic agent for IBD management. In this review, we will focus on the published evidence regarding the clinical effects of cannabis in patients with IBD.

\section{Endocannabinoid system and its mechanism of action in the GI tract}

\section{Endocannabinoids and their degrading enzymes}

Cannabis or its constituents exert their effects through CB1 and CB2 receptors, found throughout the GI system (liver, pancreas, stomach, small and large intestines (Fig. 2) [10]. Two potent endocannabinoid ligands that yield strong cannabimimetic effects are anandamide ( $\mathrm{N}$-arachidonoyl ethanolamine [AEA]) and 2-arachidonoylglycerol 


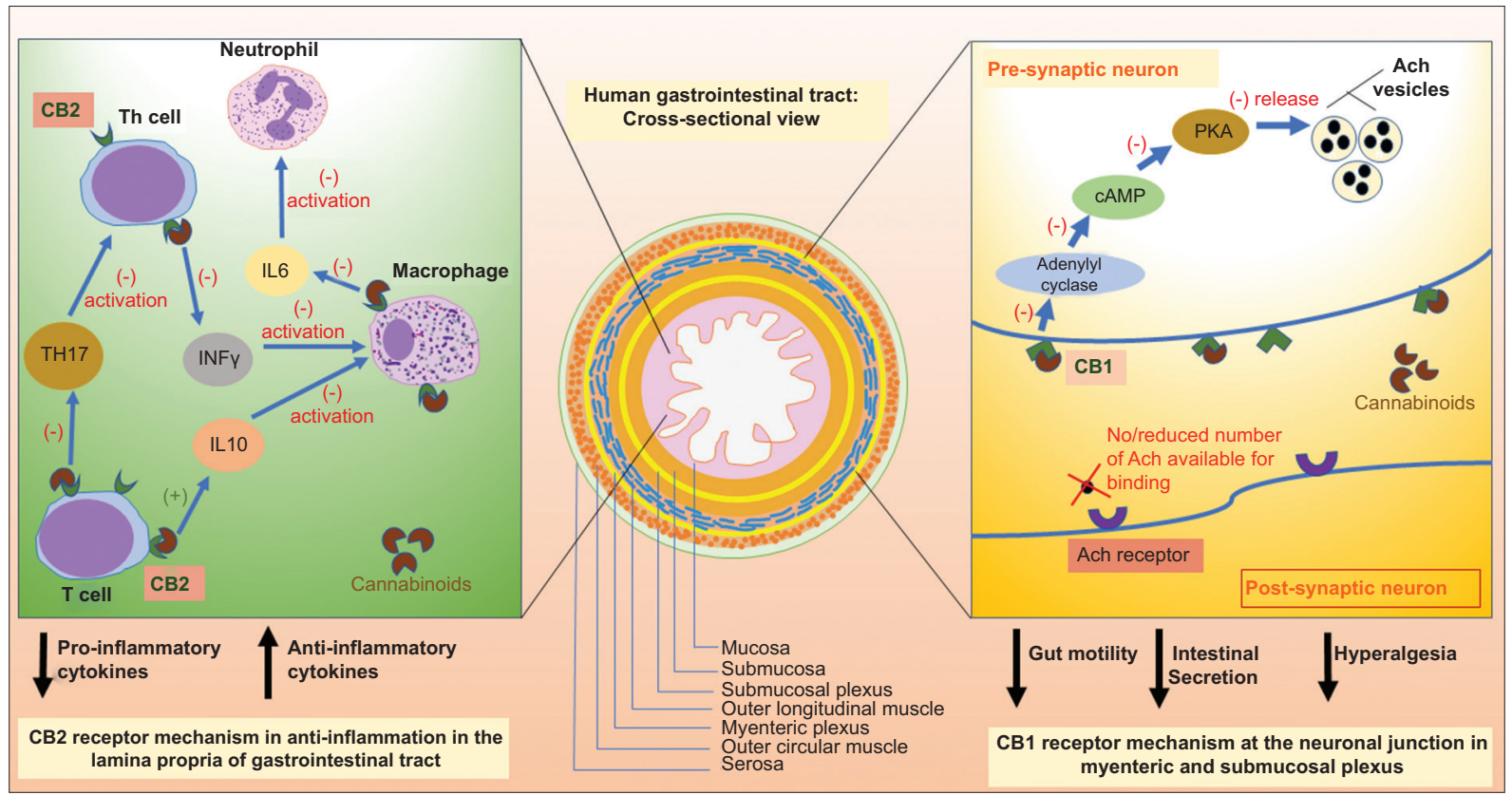

Figure 2 Mechanism of action of $\mathrm{CB} 1$ and $\mathrm{CB} 2$ receptors in the gastrointestinal tract

Th cell, Thelper cell; TH17, TH 17 cytokines; INFy, interferon-gamma; IL, interleukin; cAMP, cyclic adenosine monophosphate; PKA, protein kinase A; Ach, acetylcholine

(2-AG) [10,27]. Other endocannabinoids include noladin ether, virodhamine and $\mathrm{N}$-arachidonoyl dopamine [28]. In addition to cannabinoid receptors, endocannabinoids bind to some other receptors, including TRPV1 and GPR55 (a G-protein coupled receptor), and can exert their effects via these [10]. Endocannabinoid-degrading enzymes (fatty acid amide hydrolases [FAAH] and monoacylglycerol lipase [MAGL]) have also been identified [28]. Anandamide is degraded mainly by FAAH, but also by cyclooxygenase-2 (COX-2) and lipoxygenases (LOXs) to some extent. However, the degradation of 2-AG is complex. It is degraded by MAGL, but also sometimes acts as a substrate for COX-2, LOXs and some minor enzymes such as $\alpha / \beta$ hydrolase -6 and $\alpha / \beta$ hydrolase- 12 [29]. Endogenous ligands, together with the cannabinoid receptors and enzymes responsible for synthesizing and degrading those ligands, form the endocannabinoid system (ECS) [30].

\section{Locations of endocannabinoids in GI tract}

Functions of the CB1 and CB2 receptors are ascertained by their locations in the organ systems. In the gut, $\mathrm{CB} 1$ receptors are found in the myenteric plexus (responsible for motor control of the GI tract) and submucosal plexus (responsible for secretomotor and vasomotor actions of the gut) [27]. $\mathrm{CB} 2$ receptors are present in the immune cells, such as plasma cells and macrophages, in the lamina propria of the GI tract [31] and are also thought to be present in peripheral nerve terminals [32]. CB2 receptors have also been identified in normal colonic mucosa as well as inflamed mucosa $[31,33]$.

\section{Mechanism of actions of endocannabinoids}

Activation of $\mathrm{CB} 1$ and $\mathrm{CB} 2$ receptors produces anti-emetic, anti-motility, and anti-inflammatory effects through inhibition of adenylyl cyclase with the reduced cAMP formation (Gi/o coupled), thus blocking neurotransmitter release from a presynaptic neuron by $\mathrm{CB} 1$ and pro-inflammatory cytokine release by $\mathrm{CB} 2[34,35]$. CB1 also inhibits the activation of $\mathrm{N}$ - and $\mathrm{P} / \mathrm{Q}$ type intracellular calcium channels, decreasing calcium release, but activates inward-rectifying potassium and potassium-A channels and mitogen-activated protein kinase; together, all these mechanisms help modulate pain [27,28] (Table 1). When cannabinoids bind to the prejunctional CB1 receptors, a reduction in excitatory neurotransmission causes decreased gut motility and secretion [36]. The activation of CB1 receptors also helps control emesis by reducing excitatory neurotransmitters such as glutamate in the dorsal vagal complex (specialized vomiting center in the brainstem) [37,38]. In inflammation, some experiments with animal models showed that activation of $\mathrm{CB} 1$ also reduces peripheral inflammatory hypersensitivity and hyperalgesia, in addition to the central pain controlling mechanism $[39,40]$. On the other hand, the participation of cannabinoids in anti-inflammation through CB2 receptors has been well documented in a number of studies, including some on human cells. CB2 receptors cause phagocytosis by macrophages and also induce chemokine release $[41,42]$. AEA increases the production of tumor necrosis factor (TNF)- $\alpha$, interleukin (IL)-6, IL-12 and interferon- $\alpha$ through CB2 [43]. AEA, upon binding with CB2, also causes IL-2 secretion [44], nuclear factor- $\kappa B$-induced TNF- $\alpha$ production [45] and induced Th1 and Th17 responses, while working on T cells [46]. Cannabinoids also increase levels of 
Table 1 Cannabinoid induced modulation of gastrointestinal symptoms through CB1 and CB2 receptors

\begin{tabular}{|c|c|c|}
\hline GIT functions & CB1 receptor mechanism & $\mathrm{CB} 2$ receptor mechanism \\
\hline Vomiting & Inhibition through CNS (dorsal vagal complex) & $\begin{array}{l}\text { Co-ordination with CB1 through blockage of } \\
\text { endocannabinoid reuptake }\end{array}$ \\
\hline Gut motility & $\begin{array}{l}\text { Inhibition through myenteric plexus in } \\
\text { Gi/o-protein coupled mechanism }\end{array}$ & Not known \\
\hline Gut secretion & $\begin{array}{l}\text { Inhibition through submucosal plexus } \\
\text { modulation in Gi/o-protein coupled mechanism }\end{array}$ & Not known \\
\hline Pain (Central mechanism) & Through CNS receptors & Not known \\
\hline $\begin{array}{l}\text { Pain } \\
\text { (Peripheral hyperalgesia) }\end{array}$ & $\begin{array}{l}\text { Inhibition of C-fiber activity at peripheral } \\
\text { sensory afferents }\end{array}$ & $\begin{array}{l}\text { Possibly through receptors at peripheral nerve } \\
\text { endings }\end{array}$ \\
\hline Gut inflammation & $\begin{array}{l}\text { Through modulation of other neurotransmitters } \\
\text { secretion and producing an "entourage" effect in } \\
\text { the peripheral nerve terminals }\end{array}$ & $\begin{array}{l}\text { Anti-inflammatory, reduce pro-inflammatory } \\
\text { cytokines (TH17 and IL-6) }\end{array}$ \\
\hline $\begin{array}{l}\text { Visceral nociception } \\
\text { during inflammation }\end{array}$ & $\begin{array}{l}\text { Upregulation of CB1 in colitis induced } \\
\text { hyperalgesia }\end{array}$ & $\begin{array}{l}\text { Co-ordination with } \mathrm{CB} 1 \text { in attenuating hyperalgesia } \\
\text { with exogenous cannabinoids }\end{array}$ \\
\hline
\end{tabular}

CNS, Central nervous system; IL-6, Interleukin 6

anti-inflammatory cytokine IL-10 [47] (Fig. 2). Animal studies have also shown that the activation of CB2 receptors produces peripheral anti-nociception and reduced inflammatory edema [48]. In one study, administration of CB2 agonists (JWh133, AM1241) upregulated the CB2 receptors and reduced colonic inflammation in trinitrobenzene sulfonic acid-induced colitis in a murine model [49]. The role of CB1 receptors in inflammation is still under investigation, though some research suggests that they help combat inflammation by modulating the release of other neurotransmitters and producing an "entourage effect" in peripheral nerve terminals [50].

It has been shown that the co-activation of $\mathrm{CB} 1$ and CB2 receptors is essential for effective emesis control by endocannabinoids, possibly by blocking the endocannabinoid reuptake by CB2 [51]. A Food and Drug Administration (FDA)approved synthetic form of THC, dronabinol, has been in use for therapeutic purposes in chemotherapy-induced nausea and vomiting (for patients resistant to conventional anti-emetic therapies) and HIV-associated anorexia with weight loss since 1985 [52,53]. A synthetic oral cannabinoid, nabilone, is also now FDA-approved for the treatment of nausea and vomiting in patients on chemotherapy who fail to respond to conventional antiemetic treatments [54]. Another synthetic preparation, levonantradol, is undergoing clinical trials for the treatment of chemotherapy-induced vomiting, with promising results. However, it is not yet FDA approved [55]. Despite the widely known use of cannabinoid products for controlling various type of nausea and vomiting, cannabinoid hyperemesis syndrome can occur in patients who use it for years. It is a condition of cyclical vomiting and compulsive bathing behaviors and only gets diagnosed when other causes are ruled out [56].

\section{Prevalence of cannabis use in IBD patients}

Because of its anti-inflammatory and pain-modulating properties, a larger number of patients who suffer from chronic ailments, such as multiple sclerosis, irritable bowel syndrome or chronic seizures, are now using cannabis [19,57]. For a chronic inflammatory disease like IBD, a growing trend towards an increase in cannabis use has been seen in this patient group for symptomatic relief.

A large US population-based analysis examined data from over 2 million patients with IBD (either CD or UC) from the National Health and Nutrition Examination Survey (NHANES) and showed a higher incidence or cannabis/ hashish use in IBD patients compared to controls $(67.3 \%$ vs. $60.0 \%$ ). The age of onset of its use was also lower in IBD patients compared to those who did not have the disease (15.7 vs. 19.3 years) [7]. Lal et al conducted a crosssectional survey in Toronto, Canada, through a formulated questionnaire that asked 291 IBD patients about the current or previous use of cannabis; the results also provided supporting evidence of its increased use among this cohort. The study showed that $51 \%$ (48/95) of patients with UC and $48.1 \%(91 / 189)$ of patients of CD reported lifetime cannabis use. Among them, 33\% of cannabis users with UC and 50\% of cannabis users with CD used it for symptomatic relief. For new users, the prevalence was $12 \%(11 / 95)$ in UC patients and $16 \%(30 / 189)$ in CD patients [26]. In another similar study, $16.4 \%$ of IBD patients used it for symptom control [58]. Perhaps most alarming is the high propensity of younger individuals with IBD to use cannabis from an early age. A prospective questionnaire-based survey in a pediatric IBD clinic reported current or past use of cannabis in $70 \%$ (37/53) of IBD patients (mean age 18.7 years). Again, 70\% of these users did not report it to their gastroenterologists [59]. With the increased legalization of cannabis for both medicinal and recreational purposes, and emerging data tending to support its therapeutic application for chronic inflammatory conditions, it is likely that more patients will be willing to use cannabis for symptomatic relief if it becomes legally available [58]. 
Therapeutic applications of cannabis in IBD

\section{Crohn's disease}

\section{Clinical trials and meta-analysis}

Only a few clinical trials with small sample sizes have been conducted to examine the therapeutic effects of cannabis on IBD symptoms. Naftali et al evaluated the clinical response of inhaled cannabis in CD patients in a prospective placebo-controlled trial [24]. They recruited 21 CD (11-cannabis and 10-placebo) patients with CD Activity Index (CDAI) scores $>200$ unresponsive to conventional medications (steroids, immune-modulators, anti-TNF- $\alpha$ agents). Participants received either $115 \mathrm{mg}$ of THC b.i.d. or placebo (cannabis flower without THC) in the form of cigarettes for 8 weeks. About 45\% (5/11) of patients in the cannabis group achieved complete remission (CDAI score $<150)$ compared to only $10 \%(1 / 10)$ in the placebo group $(\mathrm{P}=0.43)$. Moreover, $10 / 11$ patients in the cannabis and $4 / 10$ patients in the placebo group showed a clinical response (a decrease in CDAI by $>100$ points; $\mathrm{P}=0.028$ ). Interestingly, quality of life was significantly improved in the cannabis group, as assessed by Short Form-36 (SF-36) questionnaire (scores: week 0: 68, week 8: 86), whereas in the placebo group no significant improvement in quality of life was noted (week 0: 71, week 8: 79) [24]. The authors concluded that, although induction of CD remission was not achieved in the study, THC produced a significant clinical and steroidfree benefit in 10 of 11 active CD patients. However, another randomized, placebo-controlled trial by Naftali et al, which included 20 patients with moderately-active conventional treatment-resistant $\mathrm{CD}$, showed that the oral (sublingual oil droplets) $10 \mathrm{mg}$ b.i.d. dose of CBD had no beneficial effects in these patients. The authors concluded that the lack of effect of CBD could be due to the small doses of CBD or to a lack of synergism with other cannabinoids [14]. Recently, a Cochrane meta-analysis evaluated the safety and efficacy of cannabis use for the induction and maintenance of remission in patients with CD. It failed to draw any definite conclusion regarding cannabis's beneficiary role in clinical remission of $\mathrm{CD}$, probably because only 3 studies with small sample sizes were evaluated [60].

\section{Observational studies}

An observational study of $30 \mathrm{CD}$ patients by Naftali et al in 2011 evaluated the disease activity, need for surgery, and hospitalization before and after cannabis use in a predominantly male cohort. Of the 30 patients, 21 reported improved disease activity (evidenced by a reduction in HarveyBradshaw Index score from $14 \pm 6.7$ to $7 \pm 4$ ), a decreased overall need for medication use, and fewer surgical procedures after the intervention (2 vs. 19) [11].

\section{Ulcerative colitis}

\section{Clinical trials and meta-analysis}

Clinical trials conducted to evaluate the effects of cannabis on patients with UC are even fewer. A 2018 multicenter, double-blind, placebo-controlled randomized, controlled trial by Irving et al studied the effects of cannabis on 60 adult UC patients [61]. The cohort was randomized into 2 groups: one consisted of 29 patients who received $50 \mathrm{mg}$ of CBD-rich botanical extracts in capsules at the beginning of the study, followed by a dose escalation period of 2 -weeks during which they were required to take capsules containing up to $250 \mathrm{mg}$ of CBD (maximum tolerated dose) and maintain that for the remaining study period. The remaining 31 patients received placebo capsules in this 10 -week-long interventional study. 17 patients in CBD group and 29 patients in placebo group completed the study. The primary endpoint (UC remission at the end of intervention with a Mayo score of $\leq 2$ ) was negative, and at the end of treatment remission rates were similar in both groups. Although the difference was statistically insignificant, per-protocol (PP) analysis (taking only those patients' data who completed the study) showed more patients in the CBD group $(7 / 17,41 \%)$ than in the placebo group $(8 / 29,30 \%)$ attained clinical remission. However, neither the intention-to-treat (ITT) analysis or per-protocol (pp) analysis did not show much statistical significance between the treatment group and placebo group (ITT analysis: odds ratio $[\mathrm{OR}]=0.82 \%$; $90 \%$ confidence interval $[\mathrm{CI}]: 0.29-0.31$; $P=0.753$ ); (PP analysis: $\mathrm{OR}=1.30$; 90\% CI: 0.42-0.44; $P=0.7\}$. Secondary endpoints such as-quality of life scores, including the physician global assessment of illness severity, the IBD questionnaire and subject global impression of changeshowed a greater improvement in the CBD group than in the placebo group on per protocol analysis. However, Naftali et al also evaluated the efficacy of cannabis use in UC patients in a randomized, placebo-controlled trial [62]. They used $23 \mathrm{mg} /$ day of THC through cigarettes (each containing $0.5 \mathrm{~g}$ cannabis), given to the experimental group over an 8-week period. Among the 28 patients who completed the study, a decrease in Disease Activity Index (DAI) for ulcerative colitis from $10 \pm 3$ to $4 \pm 3.2$ was observed in the treatment group and from $10 \pm 2.7$ to $8 \pm 2$ in the placebo group $(\mathrm{P}<0.01)$. Mayo endoscopic score was reduced in the treatment group from a median of 2 (interquartile range [IQR] 2-2.5) to 1 (IQR 0-2) $(\mathrm{P}=0.01)$, while in the placebo group there was no statistically significant change: from 2 (IQR 2-2) to 2 (IQR 1.25-2); $\mathrm{P}=0.059$. There were no serious side effects, suggesting that cannabis treatment can be effectively given to UC patients. The Cochrane meta-analysis, which included 92 patients from 2 studies as mentioned earlier, was carried out to evaluate the safety and efficacy of cannabis use in UC remission. However, it concluded that cannabis's effectiveness in UC is still uncertain, as it is based on a small number of underpowered studies with sparse data. Larger trials with proper randomization are needed to thoroughly investigate cannabis's safety profile [63]. 


\section{Studies on CD, UC, and indeterminate colitis together}

Some retrospective and prospective observational studies have also been conducted to evaluate the clinical effects of cannabis use in IBD patients. Lahat et al published a prospective study that showed an improvement in quality of life in 11 CD patients, evidenced by a reduction in Harvey-Bradshaw Index score from $11.36 \pm 3.17$ to $5.72 \pm 2.68$. They also found an improved Partial Mayo score (6 to 5) in 2 UC patients, though it cannot be counted as statistically significant because of the small sample size [25]. Allegretti et al, in a prospective cohort study, also reported significant symptom relief with cannabis use in 177 $\mathrm{CD}, 102 \mathrm{UC}$, and 13 indeterminate colitis patients. Abdominal pain, nausea, and diarrhea associated with IBD (either CD, UC or indeterminate colitis) were relieved in $89.5 \%, 72.9 \%$ and $41.6 \%$ of those cannabis users, respectively [58]. A cross-sectional study by Lal et al, comprising 291 IBD patients (191 CD, 100 UC) demonstrated significant IBD-related symptomatic relief in cannabis users: $40 / 80$ (50\%) of CD patients and 14/43 (32.6\%) of UC patients reported good effects from its use, which included relief from abdominal pain in 95\% CD and 92.8\% UC patients and from diarrhea in $22.5 \% \mathrm{CD}$ and $64.3 \%$ UC patients, and appetite improvement in $70 \% \mathrm{CD}$ and $85.7 \%$ UC patients [24]. On the other hand, a study by Storr et al in 2014 presented mixed responses to cannabis use in $231 \mathrm{CD}, 63 \mathrm{UC}$ and 25 other patients with indeterminate colitis: $56(17.6 \%)$ of these patients reported cannabis use for the control of symptoms such

Table 2 Clinical studies showing cannabis's effects on IBD

Studies showing favorable response of cannabis use in anti-inflammation/disease status improvement

\begin{tabular}{lllll}
\hline $\begin{array}{l}\text { Authors } \\
\text { (Publication year) }\end{array}$ & Sample size & Type of study & Dosage Scheme & $\begin{array}{l}\text { Mode of } \\
\text { administration }\end{array}$
\end{tabular}

\begin{tabular}{|c|c|c|c|c|c|}
\hline \multicolumn{6}{|c|}{ Studies conducted on Crohn's disease } \\
\hline $\begin{array}{l}\text { Naftali et al, } 2013 \\
{[24]}\end{array}$ & $\mathrm{n}=21$ & $\begin{array}{l}\text { Prospective, } \\
\text { Placebo- controlled }\end{array}$ & $\begin{array}{l}115 \mathrm{mg} \text { of } \Delta 9-\mathrm{THC} \\
\text { or placebo } 2 \text { times/ } \\
\text { day, } 8 \text { weeks }\end{array}$ & $\begin{array}{l}\text { Inhalation through } \\
\text { cigarette smoking }\end{array}$ & $\begin{array}{l}\text { THC: } \mathrm{CDAI}<150 \text { in } \\
5 / 11 \text { patients } \\
\text { Placebo: } \mathrm{CDAI}<150 \text { in } \\
1 / 10 \text { patients } \\
\text { Clinical response: } \\
\text { THC: decrease in } \mathrm{CDAI}>100 \\
\text { in } 10 / 11 \text { patients } \\
\text { Placebo: decrease in } \\
\text { CDAI }>100 \text { in } 4 / 10 \text { patients }\end{array}$ \\
\hline $\begin{array}{l}\text { Naftali et al, } 2011 \\
\text { [11] }\end{array}$ & $\mathrm{n}=30$ & $\begin{array}{l}\text { Retrospective, } \\
\text { Observational, } \\
\text { Single-arm }\end{array}$ & Inhalation or oral in & tion, 3-7 joints/day & $\begin{array}{l}\text { HBI: reduced from } 14 \pm 6.7 \\
\text { to } 7 \pm 4.7 \\
\text { Surgery: } \\
\text { CB: } 2 \text { pts. required surgeries } \\
\text { in } 3 \text { years of use } \\
\text { No CB: } 15 \text { pts. required } 19 \\
\text { surgeries in } 9 \text { years before } \\
\text { use }\end{array}$ \\
\hline
\end{tabular}

Studies conducted on ulcerative colitis

\begin{tabular}{|c|c|c|c|c|c|}
\hline $\begin{array}{l}\text { Naftali et al, } 2018 \\
\text { [62] }\end{array}$ & $\mathrm{n}=28$ & $\begin{array}{l}\text { Randomized } \\
\text { Placebo-controlled }\end{array}$ & $\begin{array}{l}11.5 \mathrm{mg} \text { THC or } \\
\text { placebo, } 2 \text { times/ } \\
\text { day, } 8 \text { weeks }\end{array}$ & $\begin{array}{l}\text { Inhalation through } \\
\text { cigarettes }\end{array}$ & $\begin{array}{l}\text { DAI improvement } \\
\text { THC: from } 10 \pm 3 \text { to } 4 \pm 3.2 \\
\text { Placebo: from } 10 \pm 2.7 \text { to } 8 \pm 2 \\
\text { Decrease in Partial Mayo } \\
\text { score: } \\
\text { THC: } 2(\mathrm{IQR}=2-2.5 \text { ) to } \\
1 \text { (IQR } 0-2 \text { ) } \\
\text { Placebo: } 2 \text { (IQR }=2-2 \text { ) to } \\
\text { 2 (IQR } 1.25-2 \text { ) }\end{array}$ \\
\hline
\end{tabular}

Studies conducted on both the Crohn's disease and Ulcerative Colitis

\begin{tabular}{llll}
\hline Allegretti et al, & $\mathrm{n}=292$ & Prospective, Cohort & Questionnaire based \\
2013 [58] & (CD: 177, & & purpose. \\
& UC: 102, & & Among users, \\
& indeterminate & Abdominal pain relief: $89.5 \%$ \\
& colitis: 13) & Nausea relief: $72.9 \%$ \\
& & Diarrhea relief: $41.6 \%$ \\
\hline
\end{tabular}


Table 2 (Continued)

Studies showing favorable response of cannabis use in anti-inflammation/disease status improvement

\begin{tabular}{|c|c|c|c|c|c|}
\hline $\begin{array}{l}\text { Authors } \\
\text { (Publication year) }\end{array}$ & Sample size & Type of study & Dosage Scheme & $\begin{array}{l}\text { Mode of } \\
\text { administration }\end{array}$ & Findings \\
\hline $\begin{array}{l}\text { Lahat et al, } 2012 \\
\text { [25] }\end{array}$ & $\begin{array}{c}\mathrm{n}=13 \\
(\mathrm{CD}: 11, \\
\mathrm{UC}: 2)\end{array}$ & $\begin{array}{l}\text { Open-label, } \\
\text { Prospective, } \\
\text { Single-arm }\end{array}$ & $\begin{array}{l}50 \mathrm{~g} \text { of processed } \\
\text { plants of cannabis/ } \\
\text { month; } \\
\text { Patients were } \\
\text { allowed to take } 3 \\
\text { inhalations each } \\
\text { time }\end{array}$ & $\begin{array}{l}\text { Inhalation through } \\
\text { cigarettes }\end{array}$ & $\begin{array}{l}\text { For CD patients: } \\
\text { HPS: improved from } \\
4.1 \pm 1.43 \text { to } 7 \pm 1.42 \\
\text { HBI: reduced from } \\
11.36 \pm 3.17 \text { to } 5.72 \pm 2.68 \\
\text { For UC patients: } \\
\text { Slight decrease in partial } \\
\text { Mayo Score, statistically } \\
\text { insignificant. }\end{array}$ \\
\hline $\begin{array}{l}\text { Lal et al, } 2011 \\
{[26]}\end{array}$ & $\begin{array}{c}\mathrm{n}=291 \\
(\mathrm{CD}: 191 \\
\text { UC: } 100)\end{array}$ & Cross-sectional & Questionnaire based & & $\begin{array}{l}\text { Symptomatic relief among } \\
\text { users: } \\
32.6 \% \text { UC \& } 50 \% \text { CD } \\
\text { chronic users used it for } \\
\text { symptom relief. } \\
\text { Among users- } \\
\text { Abdominal pain relief: } 92.8 \% \\
\text { in UC group, } 95 \% \text { in CD } \\
\text { Group } \\
\text { Diarrhea relief: } 64.3 \% \text { in UC } \\
\text { group, } 22.5 \% \text { in CD group }\end{array}$ \\
\hline
\end{tabular}

Studies showing no/mixed favorable response of cannabis use in anti-inflammation/disease status improvement

\begin{tabular}{|c|c|c|c|c|c|}
\hline $\begin{array}{l}\text { Authors } \\
\text { (Publication year) }\end{array}$ & $\begin{array}{l}\text { Sample Size } \\
\text { (n) }\end{array}$ & Type of study & Dosage scheme & $\begin{array}{l}\text { Mode of } \\
\text { administration }\end{array}$ & Findings \\
\hline \multicolumn{6}{|c|}{ Studies conducted on Crohn's Disease } \\
\hline $\begin{array}{l}\text { Naftali et al, } 2017 \\
\text { [14] }\end{array}$ & $\mathrm{n}=20$ & RCT & $\begin{array}{l}10 \mathrm{mg} \text { CBD or } \\
\text { placebo } 2 \text { times/day, } \\
8 \text { weeks }\end{array}$ & $\begin{array}{l}\text { Oral (sublingual) } \\
\text { administration of } \\
\text { oil drops }\end{array}$ & $\begin{array}{l}\text { CBD: } \mathrm{CDAI}=220 \pm 122 \\
\text { Placebo: } \mathrm{CDAI}=216 \pm 121\end{array}$ \\
\hline
\end{tabular}

Studies conducted on Ulcerative Colitis

\begin{tabular}{|c|c|c|c|c|c|}
\hline $\begin{array}{l}\text { Irving et al, } 2018 \\
\text { [61] }\end{array}$ & $\mathrm{n}=60$ & $\begin{array}{l}\text { Multi-center, } \\
\text { Double-blind, } \\
\text { Randomized, } \\
\text { Placebo-controlled }\end{array}$ & $\begin{array}{l}50-250 \mathrm{mg} \\
\text { botanical extract or } \\
\text { placebo in capsules, } \\
2 \text { times/day for } \\
10 \text { weeks }\end{array}$ & Oral route & $\begin{array}{l}\text { Clinical remission } \\
\text { attainment: almost equal } \\
\text { CBD: } 7 / 29 \text { patients } \\
\text { Placebo: } 8 / 31 \text { patients } \\
\text { Quality of life scores: more } \\
\text { improvement in CBD group }\end{array}$ \\
\hline
\end{tabular}

Studies conducted on both the Crohn's disease and Ulcerative Colitis

\begin{tabular}{lcll}
\hline Storr et al, 2014 & $\mathrm{n}=313$ & Cross-sectional & Questionnaire based \\
{$[64]$} & (CD: 231, & study & Symptomatic relief in CB \\
& UC: 63, & & users (abdominal pain \\
& Indeterminate & $83.9 \%$, cramping 76.8\%, \\
& diarrhea 28.6\%) \\
& & Greater odds of requiring \\
& & surgery in chronic users \\
& & (OR: 5.03\%, CI: $1.45-17.46)$
\end{tabular}

CD, Crohn's disease; UC, ulcerative colitis; THC, $\triangle 9$-tetrahydrocannabinol; CDAI, Crohn's disease activity index; CB, cannabis; HBI, Harvey Bradshaw Index; DAI, disease activity index; HPS, Health Perception Score (included general health perception, social functioning, ability to work, physical pain, depression; $C B D$, cannabidiol; OR, Odds ratio; $C I$, confidence interval

as abdominal pain (83.9\%), abdominal cramping (76.8\%), joint pain (48.2\%), and diarrhea (28.6\%). Chronic users ( $>6$ months), however, required more surgical interventions (OR 5.03, 95\% CI 1.45-17.46) [64] (Table 2).
Several factors could have roles in these conflicting results. First, in most of the studies the showed beneficial results the route of administration was through inhalation (smoking), which causes a rapid increase in active cannabis ingredients 
in the blood $[65,66]$. Second, the use of CBD instead of THC may have resulted in a weaker response, as the later possesses psychoactive components useful in pain modulation [15]. The small dosages of cannabis $(0.3 \mathrm{mg} / \mathrm{kg}$ : Naftali et al 2017 [14]; 1 g/day: Naftali et al 2018 [62]) can be considered as an important factor in these negative results, as epileptic children need $0.5-300 \mathrm{mg} / \mathrm{kg} /$ day of cannabis for treatment purpose [67]. To achieve positive results with minimal side effects, synergism among the cannabis ingredients may be necessary to achieve a satisfactory clinical response, particularly when a lower dose is used [68]. And lastly, a larger sample size comprised of diverse population could have predicted the results better, as a heterogeneous population may show dissimilar outcomes when subjected to this therapeutic option.

\section{Adverse effects and cannabis-related toxicity}

Adverse effects from cannabis use, though mild/moderate, were noted in almost every study. These included dry mouth, drowsiness, sleepiness, feeling of being "high", nausea, anxiety and paranoia, but they did not prevent the patients from participating [14,26,64]. Study-specific adverse effects are shown in Table 3.

\section{Cannabis use and its dependency potential in IBD patients compared to the general population}

As stated earlier, cannabis is already a burden with respect to its higher abuse rate among the general population. According to one report, $9 \%$ of all cannabis users, about $17 \%$ of adolescent users and $25-50 \%$ of daily users become chronic abusers [69]. Dependency and abuse potential are noteworthy problems in chronic cannabis users, because many develop mental and cognitive impairments, while cardiovascular, pulmonary and psychotic complications may occur as a result of this dependency [5,70-74]. Daily cannabis use can lead to abstinence syndrome (irritability, sleep disturbance, dysphoria, craving, anxiety) if it is ceased abruptly $[5,75]$. However, studies conducted to determine the abuse probability of dronabinol and nabilone (synthetic THCs) found no meaningful risk of addiction [76,77]. Sativex ${ }^{\circledR}$ (available in the UK), a 1:1 formulation with equal amounts of THC and CBD as a mouth spray, used in patients with multiple sclerosis for spasticity, neuropathic pain, etc., showed very low potential for abuse or dependency [15].

For IBD patients, the prevalence of cannabis use is higher than the national average and was found to be $16.4 \%$ in the USA [51], 17.6\% in Canada [57], and 10\% in Israel [23]. Studies conducted (both observational and placebo-controlled) of the effect of cannabis in IBD also failed to demonstrate any substantial abuse potential, possibly because of their smaller sample size and short duration of treatment [24]. One study showed that the prevalence of cannabis abuse is less in all GI patients than in the general population, and the same pattern was also observed for IBD patients compared to controls ( $8.57 \%$ vs. $9.96 \%$, respectively). In a large population-based analysis conducted by Weiss et al, more control subjects used cannabis for 9 days/month compared to IBD patients $(72.9 \%$ vs. $63 \%$ ), though IBD patients used higher doses for symptom control [7]. This higher-dose regimen can put these patients at higher risk of cannabis dependency. One interesting point about cannabinoids is that they can interact synergistically to augment their responses, as evidenced in some studies. One study demonstrated that a controlled fraction of multiple cannabinoids together produced better anti-hyperalgesia than a single one, which worked through vanilloid TRPV1 receptors,

Table 3 Adverse effects reported in studies conducted upon the use of cannabis on patients with Inflammatory Bowel Disease (IBD)

\begin{tabular}{|c|c|c|}
\hline Study author(s) and publication year & Study conducted upon & Adverse effects reported \\
\hline Naftali et al, 2011 [11] & $\mathrm{CD}$ & No significant adverse effects reported \\
\hline Naftali et al, 2013 [24] & $\mathrm{CD}$ & Sleepiness, nausea, mild memory loss, dizziness (only in a few patients) \\
\hline Naftali et al, 2017 [14] & $\mathrm{CD}$ & Headache, sleepiness, nausea, dizziness (NS) \\
\hline Naftali et al, 2018 [62] & UC & No serious adverse effects \\
\hline Irving et al, 2018 [61] & UC & $\begin{array}{l}\text { Severe neurological side effects (attention problem, dizziness, memory } \\
\text { impairment in a few patients), gastrointestinal disorders (nausea, dry } \\
\text { mouth, vomiting, abdominal pain, colitis, abdominal distension), lower } \\
\text { respiratory tract infection, disorientation, back pain, skin rash }\end{array}$ \\
\hline Lal et al., 2011 [26] & $\mathrm{CD}$ and $\mathrm{UC}$ & $\begin{array}{l}\text { Feeling high (easy laughing, heightened awareness) dry mouth, } \\
\text { drowsiness, paranoia, palpitations, anxiety, memory loss, hallucinations, } \\
\text { depression (all in a few patients) }\end{array}$ \\
\hline Lahat et al, 2012 [25] & $\mathrm{CD}$ and $\mathrm{UC}$ & No significant adverse effects reported \\
\hline Allegretti et al, 2013 [58] & $\mathrm{CD}$ and $\mathrm{UC}$ & Did not ask patients about adverse effects, hence not reported \\
\hline Storr et al, 2014 [64] & & $\begin{array}{l}\text { Anxiety, increased appetite, dry mouth, drowsiness, a 'high' mood } \\
\text { elevated status }\end{array}$ \\
\hline
\end{tabular}

$\overline{C D}$, Crohn's disease; UC, ulcerative colitis; NS, not significant 
rather than $\mathrm{CB} 1$ or $\mathrm{CB} 2$ [78]. $\mathrm{CBD}$ and other cannabinoids have been shown to produce an "entourage" effect, demonstrating greater efficacy [68,79]. CBD also potentiated the antinociceptive effects produced by THC alone [80]. This explains to some degree why natural marijuana (which contains multiple types of cannabinoids) produces better effects than its active ingredient THC alone [81].

\section{Future prospects}

With the plethora of research being conducted on therapeutic applications of cannabis in recent times, it is not unlikely that it might emerge as an important symptomcontrolling drug in the near future. According to the Controlled Substances Act 1970, the FDA and the Drug Enforcement Agency (DEA) still consider cannabis as a Schedule I drug (high abuse potential, non-usable as medicine, scarcity of safety data), notwithstanding its widespread legalization across the US $[16,82]$. The FDA has recently approved Epidiolex ${ }^{\circledR}$, the first-ever drug containing active cannabis ingredients, for the treatment of seizures in 2 rare forms of epilepsy [83]. Sative ${ }^{\circledR}$ has been in use for the treatment of multiple sclerosis, cancer pain, etc., in Canada, New Zealand and 21 European countries, including the UK, but is not approved in the US $[15,16]$. Researchers determined to find the implications of this "illicit"drug for therapeutic purposes have already taken their initial steps. Restrictions and regulations imposed by the DEA and FDA have posed challenges for conducting extensive research on the possible applications of medical cannabis.

\section{The question of the legality of cannabis use}

IBD patients who have never used cannabis have expressed their desire to try medicinal marijuana for the control of their symptoms, if available legally [58]. Nevertheless, the legal and social implications of the unrestrained, unregulated use of cannabis should also be considered, despite its benefits. When a history is taken from a member of the IBD population, questions about consumption of cannabis should be asked, as there seems to be a surge of cannabis use in this patient group as per the state and federal marijuana laws. With the formulation of a number of $\mathrm{CB} 1$ and $\mathrm{CB} 2$ receptor agonists and antagonists, animal model research has answered some vital questions regarding the mechanism of the ECS in health and in morbid states [2123]. Still, more in vitro and in vivo studies are needed, especially large randomized, controlled trials designed to specifically answer questions about the clinical effects of cannabis on IBD.

\section{Concluding remarks}

In this review, we have tried to comprehensively discuss the applicability of cannabis in IBD. Although some promising results in relieving IBD-related symptoms were found in a few studies, cannabis for medicinal use in IBD is still questionable, given the limited high-quality clinical evidence and the side effects. Researchers are asking for a reclassification of cannabis from Schedule I drug so that they can design safer cannabinoid derivatives for use in clinical trials. Further high-quality randomized clinical trials with larger sample size are warranted to determine the appropriate dose, route of administration, and side-effects of cannabis before it can be accepted as a possible therapeutic agent for IBD.

\section{References}

1. Zuardi AW. History of cannabis as a medicine: a review. Braz J Psychiatry 2006;28:153-157.

2. Farnsworth NR. Pharmacognosy and chemistry of "cannabis sativa". J Am Pharm Assoc 1969;9:410-414 passim.

3. Touw M. The religious and medicinal uses of Cannabis in China, India and Tibet. J Psychoactive Drugs 1981;13:23-34.

4. Leung L. Cannabis and its derivatives: review of medical use. J Am Board Fam Med 2011;24:452-462.

5. Volkow ND, Baler RD, Compton WM, Weiss SR. Adverse health effects of marijuana use. N Engl J Med 2014;370:2219-2227.

6. Azofeifa A, Mattson ME, Schauer G, McAfee T, Grant A, Lyerla R. National estimates of marijuana use and related indicators - national survey on drug use and health, United States, 2002-2014. MMWR Surveill Summ 2016;65:1-28.

7. Weiss A, Friedenberg F. Patterns of cannabis use in patients with Inflammatory Bowel Disease: A population based analysis. Drug Alcohol Depend 2015;156:84-89.

8. DISA. Map of marijuana legality by state. https://disa.com/mapof-marijuana-legality-by-state. Last updated: December 2019. [Accessed 2 January 2020].

9. European Monitoring Centre for Drugs and Drug Addiction. Cannabis legislation in Europe: an overview, Publications Office of the European Union, Luxembourg 2018. Available from: http://www.emcdda.europa.eu/system/files/publications/4135/ TD0217210ENN.pdf [Accessed 2 January 2020].

10. Naftali T, Mechulam R, Lev LB, Konikoff FM. Cannabis for inflammatory bowel disease. Dig Dis 2014;32:468-474.

11. Naftali T, Lev LB, Yablecovitch D, Yablekovitz D, Half E, Konikoff FM. Treatment of Crohn's disease with cannabis: an observational study. Isr Med Assoc J 2011;13:455-458.

12. Borrelli F, Fasolino I, Romano B, et al. Beneficial effect of the nonpsychotropic plant cannabinoid cannabigerol on experimental inflammatory bowel disease. Biochem Pharmacol 2013; 85:1306-1316.

13. Romano B, Borrelli F, Fasolino I, et al. The cannabinoid TRPA1 agonist cannabichromene inhibits nitric oxide production in macrophages and ameliorates murine colitis. Br J Pharmacol 2013;169:213-229.

14. Naftali T, Mechulam R, Marii A, et al. Low-Dose Cannabidiol is safe but not effective in the treatment for Crohn's disease, a randomized controlled trial. Dig Dis Sci 2017;62:1615-1620.

15. Robson P. Abuse potential and psychoactive effects of $\delta-9$ tetrahydrocannabinol and cannabidiol oromucosal spray (Sativex), a new cannabinoid medicine. Expert Opin Drug Saf 2011;10:675-685.

16. Rubin R. The path to the first FDA-approved cannabis-derived treatment and what comes next. JAMA 2018;320:1227-1229.

17. Goyal H, Singla U, Gupta U, May E. Role of cannabis in digestive disorders. Eur J Gastroenterol Hepatol 2017;29:135-143. 
18. Goyal H, Guerreso K, Smith B, et al. Severity and outcomes of acute alcoholic pancreatitis in cannabis users. Transl Gastroenterol Hepatol 2017;2:60.

19. Goyal H, Rahman MR, Perisetti A, Shah N, Chhabra R. Cannabis in liver disorders: a friend or a foe? Eur J Gastroenterol Hepatol 2018;30:1283-1290.

20. Pinto L, Izzo AA, Cascio MG, et al. Endocannabinoids as physiological regulators of colonic propulsion in mice. Gastroenterology 2002;123:227-234.

21. Coutts AA, Irving AJ, Mackie K, Pertwee RG, Anavi-Goffer S. Localisation of cannabinoid $\mathrm{CB}(1)$ receptor immunoreactivity in the guinea pig and rat myenteric plexus. I Comp Neurol 2002;448:410-422.

22. Massa F, Marsicano G, Hermann $\mathrm{H}$, et al. The endogenous cannabinoid system protects against colonic inflammation. J Clin Invest 2004;113:1202-1209.

23. Engel MA, Kellermann CA, Burnat G, Hahn EG, Rau T, Konturek PC. Mice lacking cannabinoid CB1-, CB2-receptors or both receptors show increased susceptibility to trinitrobenzene sulfonic acid (TNBS)-induced colitis. J Physiol Pharmacol 2010;61:89-97.

24. Naftali T, Bar-Lev Schleider L, Dotan I, Lansky EP, Sklerovsky Benjaminov F, Konikoff FM. Cannabis induces a clinical response in patients with Crohn's disease: a prospective placebo-controlled study. Clin Gastroenterol Hepatol 2013;11:1276-1280.

25. Lahat A, Lang A, Ben-Horin S. Impact of cannabis treatment on the quality of life, weight and clinical disease activity in inflammatory bowel disease patients: a pilot prospective study. Digestion 2012;85:1-8.

26. Lal S, Prasad N, Ryan M, et al. Cannabis use amongst patients with inflammatory bowel disease. Eur J Gastroenterol Hepatol 2011;23:891-896.

27. Duncan M, Davison JS, Sharkey KA. Review article: endocannabinoids and their receptors in the enteric nervous system. Aliment Pharmacol Ther 2005;22:667-683.

28. Hohmann AG, Suplita RL $2^{\text {nd }}$. Endocannabinoid mechanisms of pain modulation. AAPS J 2006;8:E693-E708.

29. Fonseca BM, Costa MA, Almada M, Correia-da-Silva G, Teixeira NA. Endogenous cannabinoids revisited: a biochemistry perspective. Prostaglandins Other Lipid Mediat 2013;102-103:13-30.

30. Di Marzo, Bisogno T, De Petrocellis L. Endocannabinoids: new targets for drug development. Curr Pharm Des 2000;6:1361-1380.

31. Wright K, Rooney N, Feeney M, et al. Differential expression of cannabinoid receptors in the human colon: cannabinoids promote epithelial wound healing. Gastroenterology 2005;129:437-453.

32. Griffin G, Fernando SR, Ross RA, et al. Evidence for the presence of CB2-like cannabinoid receptors on peripheral nerve terminals. Eur J Pharmacol 1997;339:53-61.

33. Ligresti A, Bisogno T, Matias I, et al. Possible endocannabinoid control of colorectal cancer growth. Gastroenterology 2003;125:677-687.

34. Howlett AC, Barth F, Bonner TI, et al. International Union of Pharmacology. XXVII. Classification of cannabinoid receptors. Pharmacol Rev 2002;54:161-202.

35. Evans FJ. Cannabinoids: the separation of central from peripheral effects on a structural basis. Planta Med 1991;57:S60-S67.

36. Percie du Sert N, Ho WS, Rudd JA, Andrews PL. Cannabinoidinduced reduction in antral pacemaker frequency: a telemetric study in the ferret. Neurogastroenterol Motil 2010;22:1257-1266, e324.

37. Sharkey KA, Darmani NA, Parker LA. Regulation of nausea and vomiting by cannabinoids and the endocannabinoid system. Eur J Pharmacol 2014;722:134-146.

38. Schlicker E, Kathmann M. Modulation of transmitter release via presynaptic cannabinoid receptors. Trends Pharmacol Sci 2001;22:565-572.
39. Richardson JD, Kilo S, Hargreaves KM. Cannabinoids reduce hyperalgesia and inflammation via interaction with peripheral CB1 receptors. Pain 1998;75:111-119.

40. Russo EB. Cannabinoids in the management of difficult to treat pain. Ther Clin Risk Manag 2008;4:245-259.

41. Kishimoto S, Kobayashi Y, Oka S, Gokoh M, Waku K, Sugiura T. 2-Arachidonoylglycerol, an endogenous cannabinoid receptor ligand, induces accelerated production of chemokines in HL60 cells. J Biochem 2004;135:517-524.

42. Gokoh M, Kishimoto S, Oka S, Sugiura T. 2-Arachidonoylglycerol enhances the phagocytosis of opsonized zymosan by HL-60 cells differentiated into macrophage-like cells. Biol Pharm Bull 2007;30:1199-1205.

43. Mócsai A. Diverse novel functions of neutrophils in immunity, inflammation, and beyond. J Exp Med 2013;210:1283-1299.

44. Rockwell CE, Raman P, Kaplan BL, Kaminski NE. A COX-2 metabolite of the endogenous cannabinoid, 2-arachidonyl glycerol, mediates suppression of IL-2 secretion in activated Jurkat T cells. Biochem Pharmacol 2008;76:353-361.

45. Sancho R, Calzado MA, Di Marzo V, Appendino G, Muñoz E. Anandamide inhibits nuclear factor-kappaB activation through a cannabinoid receptor-independent pathway. Mol Pharmacol 2003;63:429-438.

46. Cencioni MT, Chiurchiù V, Catanzaro G, et al. Anandamide suppresses proliferation and cytokine release from primary human T-lymphocytes mainly via CB2 receptors. PLoS One 2010;5:e8688.

47. Kozela E, Juknat A, Kaushansky N, Rimmerman N, Ben-Nun A, Vogel Z. Cannabinoids decrease the th17 inflammatory autoimmune phenotype. J Neuroimmune Pharmacol 2013;8:12651276.

48. Clayton N, Marshall FH, Bountra C, O'Shaughnessy CT. CB1 and CB2 cannabinoid receptors are implicated in inflammatory pain. Pain 2002;96:253-260.

49. Storr MA, Keenan CM, Zhang H, Patel KD, Makriyannis A, Sharkey KA. Activation of the cannabinoid 2 receptor (CB2) protects against experimental colitis. Inflamm Bowel Dis 2009;15:1678-1685.

50. Karwad MA. The role of CB 1 in intestinal permeability and inflammation. In: Couch DG TE, Sarmad S, Barrett DA, Larvin M, Wright KL, Lund JN, O'Sullivan SE (editors). The FASEB Journal 2017 p. 3267-3277.

51. Van Sickle MD, Duncan M, Kingsley PJ, et al. Identification and functional characterization of brainstem cannabinoid CB2 receptors. Science 2005;310:329-332.

52. Massa F, Monory K. Endocannabinoids and the gastrointestinal tract. J Endocrinol Invest 2006;29:47-57.

53. Highlights of prescribing information: Marinol (dronabinol) capsules, for oral use. Available from: https://www.accessdata. fda.gov/drugsatfda_docs/label/2017/018651s029lbl.pdf [Accessed 2 January 2020].

54. Highlights of prescribing information: Cesamet ${ }^{\mathrm{mw}}$ (nabilone) capsules, for oral administration. Available from: https://www. accessdata.fda.gov/drugsatfda_docs/label/2006/018677s011lbl.pdf [Accessed 2 January 2020].

55. Abrams DI. Integrating cannabis into clinical cancer care. Curr Oncol 2016;23:S8-S14.

56. Wallace EA, Andrews SE, Garmany CL, Jelley MJ. Cannabinoid hyperemesis syndrome: literature review and proposed diagnosis and treatment algorithm. South Med J 2011;104:659-664.

57. Abrams DI. The therapeutic effects of cannabis and cannabinoids: An update from the National Academies of Sciences, Engineering and Medicine report. Eur J Intern Med 2018;49:7-11.

58. Ravikoff Allegretti J, Courtwright A, Lucci M, Korzenik JR, Levine J. Marijuana use patterns among patients with inflammatory bowel disease. Inflamm Bowel Dis 2013;19:2809-2814. 
59. Phatak UP, Rojas-Velasquez D, Porto A, Pashankar DS. Prevalence and patterns of marijuana use in young adults with inflammatory bowel disease. J Pediatr Gastroenterol Nutr 2017;64:261-264.

60. Kafil TS, Nguyen TM, MacDonald JK, Chande N. Cannabis for the treatment of Crohn's disease. Cochrane Database Syst Rev 2018;11:CD012853.

61. Irving PM, Iqbal T, Nwokolo C, et al. A randomized, double-blind, placebo-controlled, parallel-group, pilot study of cannabidiol-rich botanical extract in the symptomatic treatment of ulcerative colitis. Inflamm Bowel Dis 2018;24:714-724.

62. Naftali T, Bar-Lev Schleider L, Sklerovsky Benjaminov F, Lish I, Konikoff FM. Sa1744 -cannabis induces clinical and endoscopic improvement in moderately active ulcerative colitis. Gastroenterology 2018;154 Suppl.1:S-378. [Abstract].

63. Kafil TS, Nguyen TM, MacDonald JK, Chande N. Cannabis for the treatment of ulcerative colitis. Cochrane Database Syst Rev 2018;11:CD012954.

64. Storr M, Devlin S, Kaplan GG, Panaccione R, Andrews CN. Cannabis use provides symptom relief in patients with inflammatory bowel disease but is associated with worse disease prognosis in patients with Crohn's disease. Inflamm Bowel Dis 2014;20:472-480.

65. Williamson EM, Evans FJ. Cannabinoids in clinical practice. Drugs 2000;60:1303-1314.

66. Schon F, Hart PE, Hodgson TL, et al. Suppression of pendular nystagmus by smoking cannabis in a patient with multiple sclerosis. Neurology 1999;53:2209-2210.

67. Leo A, Russo E, Elia M. Cannabidiol and epilepsy: Rationale and therapeutic potential. Pharmacol Res 2016;107:85-92.

68. Russo EB. Taming THC: potential cannabis synergy and phytocannabinoid-terpenoid entourage effects. $\mathrm{Br} J$ Pharmacol 2011;163:1344-1364.

69. Hall W, Degenhardt L. Adverse health effects of non-medical cannabis use. Lancet 2009;374:1383-1391.

70. Bolla KI, Brown K, Eldreth D, Tate K, Cadet JL. Doserelated neurocognitive effects of marijuana use. Neurology 2002;59:1337-1343.
71. Van Hoozen BE, Cross CE. Marijuana. Respiratory tract effects. Clin Rev Allergy Immunol 1997; 15:243-269.

72. Arseneault L, Cannon M, Witton J, Murray RM. Causal association between cannabis and psychosis: examination of the evidence. $\mathrm{Br} J$ Psychiatry 2004;184:110-117.

73. Jouanjus E, Goyal H. Cardiovascular complications of cannabis use. Trends Cardiovasc Med 2019;29:408-409.

74. Goyal H, Awad HH, Ghali JK. Role of cannabis in cardiovascular disorders. J Thorac Dis 2017;9:2079-2092.

75. Budney AJ, Hughes JR, Moore BA, Vandrey R. Review of the validity and significance of cannabis withdrawal syndrome. Am J Psychiatry 2004;161:1967-1977.

76. Calhoun SR, Galloway GP, Smith DE. Abuse potential of dronabinol (Marinol). J Psychoactive Drugs 1998;30:187-196.

77. Ware MA, St Arnaud-Trempe E. The abuse potential of the synthetic cannabinoid nabilone. Addiction 2010;105:494-503.

78. Comelli F, Giagnoni G, Bettoni I, Colleoni M, Costa B. Antihyperalgesic effect of a Cannabis sativa extract in a rat model of neuropathic pain: mechanisms involved. Phytother Res 2008;22:1017-1024.

79. Mechoulam R, Ben-Shabat S. From gan-zi-gun-nu to anandamide and 2-arachidonoylglycerol: the ongoing story of cannabis. Nat Prod Rep 1999;16:131-143.

80. Varvel SA, Wiley JL, Yang R, et al. Interactions between THC and cannabidiol in mouse models of cannabinoid activity. Psychopharmacology (Berl) 2006;186:226-234.

81. Carlini EA, Karniol IG, Renault PF, Schuster CR. Effects of marihuana in laboratory animals and in man. $\mathrm{Br} J$ Pharmacol 1974;50:299-309.

82. Pierre JM. Cannabis, synthetic cannabinoids, and psychosis risk: What the evidence says. Current Psychiatry 2011;10:49-57.

83. FDA news release. FDA approves first drug comprised of an active ingredient derived from marijuana to treat rare, severe forms of epilepsy. Available from: https://www.fda.gov/newsevents/ newsroom/pressannouncements/ucm611046.htm [Accessed 2 January 2020]. 